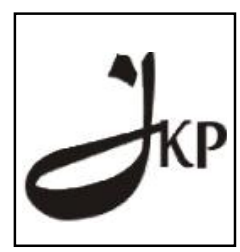

Jurnal Konseling dan Pendidikan

ISSN Cetak: 2337-6740 - ISSN Online: 2337-6880

http://jurnal.konselingindonesia.com

Volume 3 Nomor 2, Juni 2015, HIm 8-14

\title{
Efektivitas Pelatihan Asertivitas untuk Meningkatkan Perilaku Asertif Siswa Korban Bullying
}

\author{
Akhmad Rifqi Azis ${ }^{1}$ * \\ ${ }^{1}$ Fakultas Ilmu Pendidikan, IKIP PGRI Jember
}

\begin{abstract}
Abstratc
Bullying a concrete impact on the victim both physically and psychologically. The main characteristics of bullying victims is students who have not been able to be assertive. To improve the student assertive behavior bullying victim, the counselor can use assertiveness training. The purpose of this research was to know the effectiveness of assertiveness training to improve the student assertive behavior bullying victim. This research uses a pure experimental design pretest-posttest control group design. The research population was a 8 student of class VII \& VIII SMPN1 Jombang - Jember who are bullying victims. The data analysis used Two independent sample test man withney U. These results indicate that statistic score of Z (-2.323) and sig.(2-tailed) is 0.020 $<0.05$, So assertiveness training effective to improve assertive behavior student bullying victims. Suggestions of the researchers as follows: 1) for the instution of the school should give counselor should gives assertiveness training to improve the student assertive behavior bullying victims. 2) for the counselor be creative for improve assertive training module. And 3) for other researcher should use time series design and broad population so that get good generality broader.
\end{abstract}

Keyword: assertiveness training, assertive behavior, victims of bullying

Copyright (C) 2015 IICE - Multikarya Kons (Padang - Indonesia) - All Rights Reserved Indonesian Institute for Counseling and Education (IICE) Multikarya Kons

\section{PENDAHULUAN}

Maraknya perilaku kekerasan di sekolah yang tidak terkendali merupakan salah satu bentuk dari perilaku agresif atau yang lebih dikenal sebagai bullying. Bullying terjadi pada semua tingkatan sekolah mulai dari taman kanak-kanak hingga perguruan tinggi. Quiroz (dalam Anesty, 2009) mengemukakan sedikitnya terdapat tiga faktor yang dapat menyebabkan perilaku bullying yaitu hubungan keluarga, teman sebaya.

Studi pendahuluan yang dilakukan peneliti di SMPN 1 Jombang - Jember menunjukkan bahwa profil bulliying di sekolah cukup memprihatinkan, adapun data yang tercatat konselor adalah ditemukannya 17 kasus pemalakan liar, 3 kasus tawuran dengan teman sebaya, 18 kasus berkata kasar, 3 kaus menggosip, dan 28 kasus intimidasi terhadap siswa yang lemah.

Bullying adalah penggunaan kekuasaan atau kekuatan untuk menyakiti seseorang atau kelompok, sehingga korban merasa tertekan trauma dan tidak berdaya. Siswa dianggap sebagai korban bullying ketika diketahui secara berulang-ulang terkena tindakan negatif oleh pelaku bullying. Tindakan negatif tersebut termasuk melukai atau mencoba melukai atau membuat korban merasa tidak nyaman. Tindakan bullying dapat dilakukan secara fisik misalnya, pemukulan, tendangan, mendorong, dan mencekik; secara verbal misalnya

\footnotetext{
${ }_{*}^{*}$ Telp atau Alamat Email Koresponden :

akhmadrifqiazis@gmail.com
} 
memanggil nama korban dengan sebutan yang buruk, mengancam, mengolok-olok, dan fitnah. Penelitian yang dilakukan Setiawati (2012) menggambarkan bahwa bentuk bullying yang dilakukan oleh pelaku terhadap koban diantaranya sebagai berikut, bullying fisik (22,28\%); bullying verbal $(10,43 \%)$ dan bullying relasional $(6,96 \%)$.

Bullying memberikan dampak terhadap korban baik secara fisik maupun psikologis. Ketika mengalami bullying, korban merasakan banyak emosi negatif (marah, dendam, kesal, tertekan, takut, malu, sedih, tidak nyaman, terancam) namun tidak berdaya menghadapinya. Dalam jangka panjang emosi-emosi ini dapat berujung pada munculnya perasaan rendah diri bahwa dirinya tidak berharga. Para korban kesulitan menyesuaikan diri dengan lingkungan sosial, ingin pindah ke sekolah lain atau keluar dari sekolah itu, terganggu prestasi akademisnya atau sering sengaja tidak masuk sekolah. Selain itu, bullying berdampak terhadap timbul-nya gangguan psikologis, seperti rasa cemas berlebihan, selalu merasa takut, depresi, ingin bunuh diri, dan gejalagejala gangguan stres pasca-trauma (post-traumatic stress disorder), merasa hidupnya tertekan, takut bertemu pelaku bullying, bahkan depresi dan berkeinginan untuk bunuh diri.

Bimbingan dan konseling merupakan pelayananan bantuan untuk siswa, baik secara perorangan maupun kelompok, agar mandiri dan berkembang secara optimal, dalam bimbingan pribadi - sosial, belajar dan karier (Depdiknas, 2008:4). Peran konselor sebagai pelaksana bimbingan dan konseling di sekolah tentunya juga harus memberikan kontribusi dalam memberikan intervensi serta bantuan kepada seluruh siswa yang dikemas dalam layanan-layanan bimbingan dan konseling. Salah satu layanan bimbingan dan konseling untuk menangani siswa korban bullying melalui pelatihan asertivitas. Soendjojo (dalam Gowi, 2009) menjelaskan bahwa karakteristik utama korban bullying adalah siswa yang belum mampu bersikap asertif.

Cawood (1997) menyatakan perilaku asertif yaitu ekspresi yang langsung, jujur, dan pada tempatnya dari pikiran, perasaan, kebutuhan, atau hak-hak siswa tanpa kecemasan yang tidak beralasan. Langsung berarti perilaku siswa dapat menyampaikan pesan di-sampaikan dengan lugas dan wajar, serta tidak menghakimi siswa lain. Jujur berarti berperilaku menunjukkan semua isyarat pesan cocok artinya kata-kata, gerak-gerik, perasaan semuanya mengatakan hal yang sama. Sedangkan pada tempatnya berarti siswa dapat mempertahankan hak-hak dan perasaan-perasaan siswa lain maupun dirinya sendiri, waktu dan tempatnya.

Dengan memiliki perilaku asertif, siswa korban bullying lebih mudah mengekpresikan diri, terbuka secara sosial dan emosional, mencapai tujuan tanpa menghancurkan orang lain, bertanggung jawab, dan berani mengambil keputusan tanpa rasa cemas. Penelitian yang dilakukan Nurfaizal (2013:79) merekomendasikan “..pelatihan asertivitas efektif digunakan untuk meningkatkan perilaku asertif siswa”. Gowi (2010) juga menambahkan bahwa pelatihan asertivitas dapat membantu siswa korban bullying untuk meningkatkan kemampuan memahami ketakutan dan keyakinan irasional, mempertahankan hak-hak pribadi, dan menyatakan keyakinan.

Selian itu, pelatihan asertivitas terbukti efektif untuk meningkatkan keterampilan interpersonal siswa (Trisnaningtias, 2010), mereduksi kebiasaan merekok (Fidiyanti, 2009:125), meningkatkan kedisiplinan siswa (Oktariana, 2012:135), meningkatkan self esteem dan prestasi akademik siswa (Mona, 2010), meningkatkan keterampilan perilaku asertif dan mengurangi kecemasan interaksi sosial (Mousa, 2011), peningkatan harga diri (Sipayung, 2007).

Ditambahkan pula oleh Akbari (2012:12) dalam penelitiannya bahwa "pelatihan asertivitas pada masa remaja berfungsi untuk mengurangi kebimbangan, memecahkan masalah, menyelesaikan konflik, dan mengembang-kan cara-cara pengambilan keputusan". Dengan pelatihan asertivitas akan membantu siswa korban bullying untuk berperilaku asertif.

Hasil penelitian yang telah dikemukakan di atas menunjukkan bahwa pelatihan asertivitas efektif untuk menyelesaikan masalah baik itu sosial, akademik maupun kepribadian. Perilaku asertif siswa korban bullying merupakan perilaku yang menghargai diri sendiri dan orang lain, mengekspresikan perasaan positif dan negatif, mengembangkan kemampuan untuk menolak tanpa rasa bersalah, dan berani meminta bantuan orang lain ketika membutuhkan.

Fensterheim (1980) mengatakan orang yang berperilaku asertif memiliki 4 ciri yaitu merasa bebas untuk mengemukakan emosi yang dirasakan melalui kata dan tindakan. Misalnya "inilah diri saya, inilah yang saya rasakan dan saya inginkan”. Dapat berkomunikasi dengan orang lain, baik dengan orang yang tidak dikenal, sahabat, dan keluarga. Dalam berkomunikasi relatif terbuka, jujur, dan sebagaimana mestinya. Mem-punyai pandangan yang aktif tentang hidup, karena orang asertif cenderung mengejar apa yang diinginkan dan berusaha agar sesuatu itu terjadi serta sadar akan dirinya bahwa ia tidak dapat selalu menang, maka ia menerima 
keterbatasannya, akan tetapi ia selalu berusaha untuk mencapai sesuatu dengan usaha yang sebaik-baiknya dan sebaliknya orang yang tidak asertif selalu menunggu terjadinya sesuatu. Bertindak dengan cara yang dihormatinya sendiri. Maksudnya karena sadar bahwa ia tidak dapat selalu menang, ia menerima keterbatasan namun ia berusaha untuk menutupi dengan mencoba mengembangkan dan selalu belajar dari lingkungan

Hamoud (2011:1086) dalam Journal of American Science menjelas-kan bahwa "pelatihan asertivitas adalah pendekatan sistemik untuk ekspresi diri lebih tegas, didasarkan pada keseimbang-an antara pencapaian tujuan sendiri dan menghormati kebutuhan orang lain”. Trisnaningtias (2010:7) juga menambah-kan bahwa "Latihan asertif adalah latihan keterampilan yang dapat membantu seseorang berperilaku asertif, dimana perilaku asertif merupakan perilaku antar perorangan atau interpersonal yang melibatkan aspek kejujuran dan keterbukaan pikiran dan perasaan"

Corey (2005) menggemukakan bahwa secara khas prosedur atau tahapan terstruktur dalam pelatihan asertivitas adalah pertama, dimulai dengan pengenalan tentang kecemasan sosial yang tidak realistis, pemutusan pada belajar menghapus respon-respon internal yang tidak efektif yang telah mengakibatkan kurang tegasnya dan mempelajari peran tingkah laku baru yang asertif. Kedua, memperkenalkan sejumlah latihan relaksasi, dan masing-masing anggota menerangkan tingkahlaku spesifik dalam situasi-situasi interpersonal yang disarankan menjadi masalah. Para anggota kemudian membuat perjanjian untuk menjalankan tingkahlaku spesifik dalam situasi-situasi interpersonal yang dirasakan menjadi masalah. Para anggota kemudian membuat perjanjian untuk menjalankan tingkahlaku menegaskan diri yang semula mereka hindari sebelum memasuki sesi berikutnya. Ketiga, para anggota menerangkan tentang tingkahlaku menegaskan diri yang telah dijalankan oleh mereka dalam situasi-situasi kehidupan nyata. Mereka berusaha mengevaluasi dan jika mereka belum sepenuhnya berhasil, kelompok langsung menjalankan permainan. Keempat, bisa disesuaikan dengan kebutuhan-kebutuhan individual para anggota. Sejumlah kelompok cenderung berfokus pada permainan peran tambahan, evaluasi dan latihan, sedangkan kelompok lainnya berfokus kepada usaha mendiskusikan sikap-sikap dan perasaan-perasaan yang telah membuat tingkahlaku menegaskan diri sulit dijalankan.

Penelitian ini diharapkan dapat memberikan manfaat baik secara teoritis maupun praktis. Manfaat teoritis yaitu Untuk pengembangan ilmu bimbingan dan konseling, khususnya pelatihan asertivitas dan perilaku asertif siswa korban bullying, dan memberikan pemahaman dan gambaran tahapan pelatihan asertivitas dalam meningkatkan perilaku asertif siswa korban bullying. Manfaat praktis penelitian ini adalah memberikan masukan bagi sekolah tetang pentingnya pelatihan asertivitas untuk meningkatkan perilaku asertif siswa korban bullying, meberikan pengetahuan kepada konselor dalam memberikan pembinaan pelatihan asertivitas secara periodik terhadap siswa korban bullying, memberikan bahan rujukan kepada penelitian selanjutnya yang berkaitan dengan penanggulangan siswa korban bullying dan pelatihan asertivitas.

METODE

Penelitian ini menggunakan pretest-posttest group control design. Subjek penelitian ini adalah 8 siswa kelas VII \& VIII SMPN 1 Jombang - Jember yang menjadi korban bullying, kemudian subjek penelitian dibagi dalam kelompok eksperimen (konseli yang mendapatkan intervensi pelatihan asertivitas) dan kelompok kontrol (konseli yang mendapatkan intervensi bimbingan pribadi sosial). Pengumpulan data dengan skala perilaku asertif.

Analisis data menggunakan uji Two independent sample test man whithney $U$, yang digunakan untuk mengetahui ada atau tidaknya perbedaan dari dua himpunan data yang berasal dari sampel yang bebas dengan bentuk data oridinal dan memiliki sampel dibawah 30. Dalam pengujian hipotesis, dasar pengambilan keputusan adalah dengan membandingkan angka $\mathrm{Z}$ hitung dan $\mathrm{Z}$ tabel, yaitu jika $\mathrm{Zh}>\mathrm{Za}$ maka Ho ditolak. Dengan melihat angka probalitas dengan ketentuan, jika $\mathrm{P}>0,05$, maka Ho diterima, jika $\mathrm{P}<0,05$, maka Ho ditolak.

\section{HASIL}

\begin{tabular}{cccccc} 
Variabel & $\mathrm{N}$ & Mean Rank & Sig. & Ket. & Kesimpulan \\
\hline $\begin{array}{c}\text { Kel. } \\
\text { Eksperimen }\end{array}$ & 4 & 6.50 & 0,020 & $\begin{array}{c}\text { Sig } \\
<0,05\end{array}$ & $\begin{array}{c}\text { Terdapat perbedaan nilai rata-rata kelompok } \\
\text { eksperimen dan kelompok kontrol }\end{array}$ \\
\hline Kel. Kontrol & 4 & 2.50 & & & \\
\hline
\end{tabular}

Berdasarkan hasil analisis, maka hipotesis diterima dan dapat disimpulkan bahwa pelatihan asertivitas efektif untuk meningkatkan perilaku asertif siswa korban bullying. 


\section{PEMBAHASAN}

Berdasarkan hasil penelitian, peneliti memperoleh temuan bahwa perilaku asertif siswa korban bullying pada kelompok eksperimen dan kelompok kontrol sebelum diberikan intervensi pelatihan asertivitas berada pada kategori rendah dan sedang. Terdapat tiga hal yang mempengaruhi rendahnya tingkat perilaku asertif siswa korban bullying diantaranya yaitu siswa masih belum mampu mengungkapkan perasaan negatif, afirmasi diri dan mengungkapkan perasaan positif.

Berdasarkan tenemuan penelitian siswa korban bullying masih belum mampu mengekspresikan rasa ketidak-senangan terhadap teman, mempertahan-kan hak yang semestinya ia dapatkan, menolak ajakan/ permintaan teman, mengungkapkan pendapat, memberikan pujian kepada teman yang berprestasi, mengungkapkan perasaan cinta dan tidak berani meminta pertolongan apabila mengalami kesulitan. Tenemuan penelitian ini mendukung pernyataan Galassi (dalam Porpitasari, 2007) bahwa aspek-aspek perilaku asertif terdapat tiga kategori yaitu expressing positive feelings, self affirmations and expressing negative feelings.

Tenemuan kedua adalah siswa yang korban bullying mayoritas meiliki ciri fisik yang lebih kecil dari pada pelaku, pemalu, siswa baru, beda agama, memiliki uang saku banyak. Tenemuan penelitian kedua ini mendukung pernyataan Cloroso (2006) bahwa karakteristik korban bullying adalah siswa baru, penurut, takut berkelahi, kaya, berbeda etnis dan agama, cerdas, dan memiliki ciri fisik yang berbeda.

Tenemuan ketiga adalah sebelum mendapatkan pelatihan asertivitas, siswa cendrung takut, cemas, kurang percaya diri dalam bergaul dan trauma. Tenemuan penelitian ini mendukung pernyataan Rigby (2002) bahwa korban bullying dapat mengalami berbagai macam gangguan yang meliputi kesejahteraan psikologis yang rendah (low psychological well-being) sehingga korban akan merasa tidak nyaman, takut, rendah diri serta tidak berharga, introvert, memiliki harga diri yang rendah dan kurangnya keterampilan sosial.

Pelatihan asertivitas dapat diarti-kan sebagai suatu program pelatihan sistemik untuk mengekspresikan diri lebih tegas, didasarkan pada keseimbangan antara pencapaian tujuan itu sendiri dan menghormati kebutuhan orang lain. Pengertian ini senada dengan pendapat Hamoud (2011:1086) bahwa pelatihan asertivitas adalah pendekatan sistemik untuk mengekspresikan diri lebih tegas dan menghormati kebutuhan orang lain.

Ada tiga prosedur yang digunakan peneliti dalam pelatihan asertivitas yaitu menghapus rasa takut yang berlebihan dan keyakinan tidak logis. Prosedur ini lebih menekankan pada menghapus kecemasan dan rasa takut yang dialami siswa korban bullying di sekolah. Kegiatan yang dilakukan dalam pertemuan ini adalah peneliti memberikan tayangan film "bawang merah dan bawang putih" yang memberikan gambaran kecemasan dan rasa takut berlebihan yang dialami oleh bawang putih, kemudian peneliti mengajak siswa untuk menganalisis rasa takut dan keyakinan tidak logis bawang putih, kemudian dilanjutkan dengan mengaitkan permasalahan yang dialami bawang putih dengan fakta-fakta yang dialaminya.

Berdasarkan hasil analisis rasa takut dan keyakinan tidak logis serta mengaitkan fakta-fakta yang dialaminya tenemuan peneliti yang kelima adalah siswa sering menyendiri di saat jam istirahat, tidak masuk sekolah dan pulang sekolah dengan tergesa-gesa. Tenemuan keempat penelitian ini mendukung penyataan Swearer (2009) bahwa secara psikologis, dampak yang dialami korban bullying adalah anak-anak tercatat lebih menyendiri, lebih baik menghindari sekolah dan kurang memiliki harga diri.

Setelah siswa mengetahui dan menyadari bahwa yang ia alami adalah kecemasan dan keyakinannya tidak logis, peneliti mengajaknya untuk berdiskusi dan memberikan nasihat bahwa rasa cemas dan keyakinannya tidak logis yang diekspresi-kannya adalah kuarang baik untuk pengembangan kepribadiaannya. Hasil evaluasi pertemuan pertama yaitu anggota kelompok eksperimen mampu meng-analisis rasa cemas dan keyakinan tidak logis, selain itu anggota kelompok eksperimen juga merasa lega karena telah menyadari bahwa keyakinan dan kecemasannya kurang baik dalam pengembangan kepribadiannya.

Prosedur kedua dalam penelitian ini adalah berlatih untuk bersikap asertif, dalam prosedur ini lebih menekankan pada latihan bersikap asertif dalam menghadapi pelaku bullying. Kegiatan yang dilakukan dalam pertemuan ini adalah latihan mengungkapkan perasaan positif, afirmasi diri dan mengungkapkan perasaan negatif. Sebelum berlatih peneliti memutarkan Film "perilaku asertif, agresif dan non asertif", setelah menonton film anggota kelompok eksperimen diajak untuk menganalisis isi film tersebut dan mem-bagikan angket analisis perilaku asertif, non asertif dan agresif. Hasil analisis tersebut menunjukkan bahwa anggota kelompok eksperimen telah mampu membedakan perilaku asertif, non asertif dan agresif.

Selain memberikan lembar analisis perilaku asertif, non asertif dan agresif dalam prosedur ini peneliti melatih anggota kelompok eksperimen untuk mengungkap-kan perasaan negatif misalnya mengungkapkan 
ketidak-senangan dan kemarahan; afirmasi diri misalnya mem-pertahankan hak mutlak, menolak permintaan, dan meng-ungkapkan pendapat; mengungkapkan perasaan positif misalnya memberi dan menerima pujian, meminta bantuan apabila mengalami kesulitan, mengungkapkan perasaan suka dan simpati, memulai dan terlibat dalam percakapan.

Prosedur ketiga dalam penelitian ini adalah berlatih menghadapi situasi yang sulit dengan bermain peran perilaku asertif dan menerapkannya dalam kehidupan nyata. Kegiatan ini menekan-kan pada bermain peran perilaku asertif dalam suatu permasalahan yang sulit. Peneliti menyiap-kan skenario drama "Persahabatan di Sekolah", dalam drama ini terdapat dua pemeran yaitu Upin dan Ipin, Upin adalah anak yang rajin dan berprestasi sedangkan Ipin adalah anak suka mem-bully temannya. Hasil dari bermain peran ini adalah anggota kelompok eksperimen mampu meng-hadapi situasi yang sulit dengan sikap asertif.

Berdasarkan pernyataan di atas, peneliti menyimpulkan bahwa perilaku asertif memiliki peran penting dalam meningkatkan perilaku asertif siswa korban bullying. Hal ini menguatkan pendapat Nurfaizal (2013:79) bahwa pelatihan asertivitas efektif untuk meningkatkan perilaku asertif siswa. Selain itu Corey (2009:134) mengungkap-kan bahwa pelatihan asertivitas dapat meningkatkan perilaku asertif karena dalam pelatihan asertivitas terdapat komponen yang meliputi pertama, menghapuskan rasa takut yang berlebihan dan keyakinan tidak logis. Rasa takut yang berlebihan siswa korban bullying, termasuk ketakutan disakiti orang lain. Ketakutan kedua yaitu bila siswa korban bullying merasa gagal memaksa orang untuk mencintai dirinya. Ketakutan ketiga adalah siswa korban bullying memandang bahwa perilaku tegas adalah sebuah perilaku yang kurang sopan dan tidak menghargai orang lain dan dapat menampilkan diri sebagai orang yang tidak mampu, tidak mahir, dan tidak berguna. Ketakutan yang berlebihan dan keyakinan yang irasional sering menghentikan siswa korban bullying yang akan bersikap tegas.

Kedua, menerima dan mengemukakan fakta-fakta masalah yang akan dihadapi. Siswa korban bullying menerima bahwa setiap orang harus mampu bersikap tegas dan mengekspresi-kan pikiran, perasaan, dan keyakinan secara jujur.

Ketiga, berlatih untuk bersikap asertif sendiri. Latihan bersikap tegas sendiri biasanya menggunakan refleksi atau permainan peran jiwa dimana dalam situasi ini siswa korban bullying akan lebih bisa bersikap asertif, memusatkan pada perilaku nonverbal yang penting dalam ketegasan.

Keempat, menempatkan individu dengan orang lain untuk bermain peran pada situasi yang sulit. Tahap keempat menyediakan kesempatan siswa korban bullying untuk berlatih peran dan men-dapatkan umpan balik orang lain. Pelatihan lebih lanjut mengizinkan siswa korban bullying untuk lebih lanjut menunjukkan perubahan perilaku dan membiasakan siswa untuk dan menerap-kan timbal bersikap lebih tegas. Menggandakan latihan juga membuat siswa korban bullying semakin bertambah nyaman dan senang saat menjadi asertif.

Kelima, membawa perilaku asertif pada kondisi yang sebenarnya atau dalam kehidupan sehari-hari. Siswa korban bullying membuat kontrak perilaku untuk melaksanakan perilaku asertif yang sebelumnya dihindari. Pada sesi selanjut-nya, siswa korban bullying menjelaskan pengalamannya, menilai usaha yang di-lakukan, hubungkan dalam latihan selanjut-nya dan membuat kontrak perilaku lain untuk keluar dari pengalaman asertif kelompok.

Pelatihan asertivitas dilakukan selama lima kali pertemuan, satu kali pertemuan digunakan untuk praintervensi, tiga kali pertemuan digunakan untuk intervensi, satu pertemuan digunakan untuk terminasi dan evaluasi. Pertimbang-an peneliti menggunakan pertemuan ke lima untuk terminasi dan evaluasi karena dalam pertemuan ini peneliti dapat mengamati keterampilan yang telah dipelajari. Berdasar-kan hasil pengamatan siswa mampu menerapkan keterampilan yang sudah dipelajari seperti mengungkap-kan perasaan negatif, afirmasi diri dan mengungkapkan perasaan positif.

Sesuai dengan tujuan penelitian yaitu untuk mengetahui efektivitas pelatihan aserivitas untuk meningkatkan perilaku asertif siswa korban bullying. Hal ini dapat dilihat dari hasil posttest yang menunjukkan signifikasi antara kelompok eksperimen dan kelompok kontrol adalah 0,020. Berdasarkan pada penyataan di atas, dapat disimpulkan bahwa setelah meng-ikuti pelatihan asertivitas, siswa korban bullying mampu bersikap asertif dalam menghadapi permasalahannya; siswa memperoleh keterampilan mengungkapkan perasaan negatif, afirmasi diri dan mengungkapkan perasaan positif. 


\section{KESIMPULAN DAN SARAN}

Berdasarkan hasil penelitian dan pembahasan dapat disimpulkan bahwa pelatihan asertivitas efektif untuk meningkatkan perilaku asertif siswa korban bullying.

Berdasarkan hasil penelitian dapat diberikan saran - saran kepada pihak ter-kait sebagai berikut: 1) Sekolah hendak-nya menyelenggarakan pelatihan asertivitas untuk meningkatkan perilaku asertif siswa korban bullying. 2) Konselor hendaknya lebih kreatif baik waktu pelaksanaan pelatihan maupun bahan intervensi pelatihan asertivitas. 3) Bagi peneliti selanjutnya hendaknya meng-gunakan rancangan penelitian time series design dan populasi yang lebih banyak sehingga memperoleh generalisasi yang lebih luas.

\section{DAFTAR RUJUKAN}

Agbakwuru, C., \&Stela, U. 2009. Effect Asertiveness Training on Resilience Among Early-Adolance. European Sciensific Journal. May Edition Vol.8 No. 10.

Akbari, B., \& Soraya, S. 2012. Effect of Assertiveness Training Methods on Self Esteem and General SelfEficacy Female Students of Islamic Azad University, Anzali Branch. Journal of Basic and Applied Scientific Research 2265-2269.

Alberti, R. E. \& Emmons, M. L. 2008. Your Perfect Right: Assertiveness and Equality in Your Life and Relationships (9th ed.). Atascadero, CA: Impact Publishers.

Anesty, E. 2009. Konseling Kelompok Behavioral Untuk Mereduksi Perilaku Bullying siswa SMAN 10 Bandung. Skripsi. Tidak Diterbitkan. Bandung : UPI.

Arikunto, S. 2002. Prosedur Suatu Penelitian: Pendekatan Praktek. Edisi Revisi. Rineka Cipta: Jakarta.

Azwar, S. 2000. Reliabilitas dan Validitas. Yogyakarta: Pustaka Belajar.

Besag, V. E. 1989. Bullies and Victims in Schools. Washington: Open University Press.

Coloroso, B. 2006. Penindasan, Tertindas, dan Penonton; Resep Memutus Rantai Kekerasan Anak dari Prasekolah hingga SMU. Terjemahan oleh Santi Indra Astuti. Jakarta: Serambi.

Corey, G. 2005. Theory and Practice of Counseling \& Psychotherapy. Belmont: Thomson.

Corey, G. 2009. Teori dan Praktek Konseling dan Psikoterapi. Bandung: PT. Refika Aditama.

Cowood, R. 1997. And Asserts That for Companies to Survive.

Daryono. 2011. Program Bimbingan \& Konseling Komprehensif dalam Upaya Mengembangkan Kecerdasan Emosional Siswa SMA.Tesis. Tidak Diterbitkan. Bandung : UPI.

Depdiknas. 2007. Rambu-rambu Penyelenggaraan Pelayanan Bimbingan dan Konseling dalam Jalur Pendidikan Formal. Jakarta: Depdiknas.

Mahmud M. 2005. Desain Penelitian. Alfabeta: Bandung.

Marini, L., \& Andriani, E. (2005). Perbedaan Tingkat Asertivitas Remaja Ditinjau dari Pola Asuh Orang Tua. Jurnal Psikologia.

Mona M., Promila, S. (2010). "Efektivitas Program Asertif Training untuk Meningkatkan Self Esteem dan Prestasi Akademik pada Remaja”. International Research Journal. 1, (11).

Mousa, A., \& Amira Y.S. 2011. The Effect of An Assertiveness Training Program on Assertiveness Skill and Social Interaction Anxiety of Individuals with Schizophrenia. Journal of American Science 254-466.

Nurfaizal. 2013. Efektivitas Assertive Training untuk Meningkatkan Perilaku Asertif Siswa. Tesis. Tidak Diterbitkan. Bandung : UPI.

Olweus, D. 1993. Bullying at School:What We Know and What We Can Do. Oxford: Blackwell.

Okezone.com. Geng Motor di Sekolah. (Online), (http://www.okezone.com) diakses 07 Oktober 2012.

Oktariana, Y. 2012. Program Bimbingan Pribadi Sosial Menggunakan Assertive Training untuk Meningkatkan Kedisiplinan Siswa. Tesis. Tidak Diterbitkan. Bandung: UPI.

Peraturan Pemerintah No. 29 Tahun 1990 Tentang Pendidikan Menengah. 1990. Jakarta: PT. Armas Duta Jaya. Porpitasari, D. M. 2007. Pengaruh Perilaku Asertif Terhadap Hubungan Interpersonal pada Siswa Kelas XI SMK Islam 1 Blitar. Skripsi. Tidak Diterbitkan. Bandung: UPI.

Radar Jember. 23 Januari 2013. Pelaku Bullying di SMAN 1 Jember di Tuntut 5 Bulan Penjara. Hal. 15-19.

Rigby, K. 2002. A New Perspective on Bullying. London: Jessica Kingsley.

Rivers, I. 2007. Bullying: A Handbook for Educators and Parents. London: Praeger Publisher. 
RRI. 29 Desember 2012. Polisi Membubarkan Aksi Tawuran Antarpelajar SMKN 2 Jember dengan SMAN 3 Jember.

Riauskina, I., Djuwita, R., Soesetio., \& Sri, R. 2005. "Gencet-Gencetan” di Mata Siswa/Siswi Kelas I SMA : Naskah Kognitif Tentang Arti Skenario, dan Dampak "Gencet-Gencetan”. Jurnal Psikologi Sosial. Vol. 12. Nomor. 01, September. Fakultas Psikologi Universitas Indonesia.

Santosa, J. S. 1999. Peran Orang Tua dalam Mengajarkan Asertivitas pada Remaja. Anima, Indonesian Psychological Journal.

Setiyawati, T. M. 2012. Efektivitas Konseling Kelompok Melalui Teknik Role Playing Untuk Menangani Perilaku Bullying: Studi Kuasi Eksperimen Terhadap Siswa Sekolah Dasar Laboratorium Percontohan UPI Bandung. Tesis. Tidak Diterbitkan. Bandung : SPS UPI.

Sipayung. 2007. Efektifitas Pelatihan Asertivitas untuk Meningkat Harga Diri Siswa. Jurnal fakultas psikologi UNDIP 1-13.

Siswanti. 2009. Fenomena Bullying di Sekolah Dasar Negeri di Semarang : Sebuah Studi Deskriptif. Jurnal Fakultas Psikologi UNDIP 1-13.

Surya.1988. Bimbingan Pribadi Sosial. Alfabeta: Bandung.

Suryabrata. 2006. Validitas \& Reabilitas Instrumen. Yogyakarta: Pustaka Belajar.

Swearer, S. M. 2009. Bullying Prevention and Intervention: Realistic Strategies for Schools. New York: Guilford Press.

Trisnaningtias, E. 2010. Penerapan Latihan Asertif Untuk Meningkatkan Komunikasi Interpersonal.

Tuckman, B.W. 1999. Conducting Educational Research, 5th Edition. Orlando. FL: Harcourt Brace.

Undang-undang Nomor 20 tahun 2003 Tentang Sistem Pendidikan Nasional. 2003. Jakarta: PT Armas Duta Jaya.

Univesitas Negeri Malang. 2006. Pedoman Penulisan Karya Ilmiah: Skripsi, Tesis, Disertasi, Artikel, Makalah, Laporan Penelitian Cetakan Keempat. Malang : Universitas Negeri Malang.

Webster's Third New International Dictionary.1993. Merriam Webster Inc. USA.

Wilis, S. 2004. Praktek Konseling. Bandung: Alfabeta.

Winkel, W.S. 1997. Bimbingan dan Konseling. Jakarta: PT. Grafindo.

Yusuf, S. 2008. Psikologi Perkembangan Remaja. Bandung: Rosda. 